\title{
Impact of the Increase in Library Doctorates
}

\begin{abstract}
A questionnaire was mailed to recipients of library doctoral degrees between 1930 and 1975 to determine the present and preferred areas of activity, evaluations of the doctoral degree as a factor in obtaining and performing present duties, and self-assessments of involvement in library research. Further, through an examination of position advertisements over a six-month period, the relative importance of a doctorate and other factors such as experience and special skills were weighed for positions in library education and academic library administration, and the dangers of potential fragmentation and compartmentalization based on these requirements are evaluated.
\end{abstract}

$I_{1}$ N 1970 RAY AND PATRICIA CARPENTER postulated an insufficient number of doctorates for the needs of librarianship. ${ }^{1}$ They based this conclusion primarily on the number of faculty positions in existence (or about to come into existence) and assumed that such posts should be filled to a far greater extent by doctoral graduates.

The research reported in the present paper consists of two studies. The first is a survey of employment listings in library administration and education to test the Carpenter hypothesis and to determine how necessary the degree is as a credential for employment. The second is a survey of present holders of library doctorate degrees to determine how they perceive the importance of the degree to the performance of their tasks and to attempt a relationship between their academic credentials and their research scholarship.

Since the Carpenter study, which identified 249 earned doctorates through 1968,

Herbert S. White is professor, Graduate Library School, and director, Research Center for Library and Information Science, Indiana University, Bloomington. Karen Momenee is lecturer, Graduate Library School, Indiana University. This article is based on a study that received one of the 1977 Research Competition awards presented by the ALA Library Research Round Table. there has been a substantial acceleration in the production of terminal degrees in librarianship. While the availability of federal support funds in the late 1960s and early 1970 s served to provide considerable impetus for this program, the acceleration can now be expected to continue almost on its own momentum, if for no other reason than the fact that a large and growing number of accredited library schools are now involved in or committed to the establishment of library doctorate programs. They can be expected to recruit vigorously for students to keep their programs alive.

Although specific statistics vary, through the examination of the Eyman list of doctoral dissertations through $1972^{2}$ and a specific screening of Dissertation Abstracts, we identified 280 such doctorates during the period in which the Carpenters reported 249. Similarly, Nancy Lane, in her 1975 doctoral dissertation, ${ }^{3}$ located 289 library doctorates through 1969 , while we were able to identify 308 during this same period. Since degrees granted in one year are sometimes not reported in Dissertation Abstracts until several years later, the discrepancy can be accounted for in this manner.

The growth of library doctoral degrees has been startling. We were able to identify 662 library doctorates granted by graduate library school programs at accredited library schools through 1975 . (Since only those 
1975 dissertations reported through August 1976 in Dissertation Abstracts are included, there may in fact be a few more.) Of these degrees, better than half have been granted since 1969 and better than one-quarter since 1972. There was a slight drop in 1974 but a resurgence in 1975. Even at present levels, which can be expected to increase as neophyte programs get into full swing, we will cross the 1,000 threshold by 1980 . The 1930-50 cumulative total, which doubled in 1959, doubled again in 1967 and again in 1973. It will once again have doubled in 1980 or 1981.

\section{ADVERTISEMENTS FOR POSITIONS}

To determine what jobs specifically call for this new influx of doctoral degree holders, advertisements for professional librarians were checked over a six-month period, from June 1976 to December 1976, in Chronicle of Higher Education, Library Journal, College \& Research Libraries News, Wilson Library Bulletin, L.J. Hotline, and a number of other publications.

Two kinds of positions were screened, those that requested candidates for library school teaching posts and those that offered head administrative posts in academic libraries. It was felt that these were the two kinds of positions for which the doctorate in librarianship would be most appealing, and spot checks of other kinds of positions bear out this assumption. The requirement of a doctorate, or its desirability, was not mentioned to any significant extent for any library post other than the two types mentioned above. During the period studied, forty-six library school faculty positions were advertised. Of these, ten were in schools whose programs are not accredited by the American Library Association, thirty-six in programs that are accredited by ALA. Of these thirty-six, there were seventeen in schools with active doctoral programs.

Thirty-nine of the forty-six advertisements categorically stated the requirement of a doctorate of some kind as a qualification for the position. Twenty-three specified a library doctorate, and sixteen indicated that a subject doctorate would be an acceptable alternative. There was little difference in the kind of school and the kind of program, although it might be expected that a school with an active Ph.D. training program might have a greater demonstrated need for this qualification than one that, for example, prepared largely school librarians in an unaccredited setting. Fifteen of the seventeen positions at doctorate-granting schools required a doctorate, although four were willing to accept subject degrees in lieu of library degrees. The other two advertisements indicated a strong preference for the library doctorate but did not absolutely demand it.

Of the nineteen positions at accredited library schools without doctoral programs, eighteen absolutely required the doctorate, although a surprisingly high number of twelve found a nonlibrary doctorate an acceptable alternative. The remaining school indicated its preference though not requirement for a subject rather than library doctorate. Of ten positions in unaccredited schools, six absolutely required the library doctorate, the other four preferred but did not insist on a doctorate and were equally divided in preference between library and subject specializations. Other skills, such as teaching ability and professional experience, were also required for twenty-two of these twenty-six positions, but in no case were these spelled out with any specificity.

For the twenty-five university and twenty-eight college head administrative positions advertised during this same period, the reverse tendency applied. Twenty-three of the university and twenty-seven of the college head administrative posts specified exact requirements of administrative experience (in years), specific skills in management, budgeting, automation, public relations, etc. Only five of the fifty-three absolutely required a doctorate, and for four of them it was a subject and not a library doctorate. Another twenty-one expressed the preference for a doctorate, with five preferring the library field, six a subject field, and eleven accepting either. The remaining twenty-seven job postings mentioned no doctorate at all.

The pattern appears to be clear. While the trend for library education posts has been toward the doctorate, the trend in administrative posts has been away from the doctorate and toward a demonstrated ability to manage. The most dramatic evidence for 
this comes in a study by Kaser, which reports that in 196090 percent of ARL (Association of Research Libraries) head librarians had achieved doctorates. In 1976 this had dropped to 15 percent of ARL library administrators. ${ }^{4}$

\section{SURVEY OF DOCTORATES}

We attempted to relate these findings to the self-perceptions of library degree holders. As stated, we identified 662 doctorates granted by library schools accredited by the American Library Association between the years 1930 and 1975. Of these, twentyseven recipients were deceased. Another thirty-seven were foreign students who had returned to their native countries after receipt of their doctorates and were excluded because they represented special cases of no direct bearing to American librarianship. Finally, twenty-eight recipients could not be located, despite the excellent cooperation of alumni offices. Questionnaires were mailed to the remaining 570. Two of these individuals responded but disqualified themselves because they had been retired for some time, and they were dropped from the sample. Of the remaining 568 subjects, responses were received from 403 . The response rate of 71 percent matches exactly the level of response achieved by the Carpenter study and provides ample evidence of the high degree of interest in and concern about this topic.

Further evidence of interest can be inferred from the fact that 31 percent of all respondents took the trouble to append specific comments to their questionnaires, some considerably elaborated. These comments ranged from cautions about overinterpretation of self-evaluative data to expressions of high interest in learning the results of the survey. Perhaps of greatest interest were lengthy explanations for selfperceived paucity of research, despite the fact that, in a totally anonymous survey such as this one, no conclusions about individuals could be drawn. A large number of respondents felt obliged to explain what to them was obviously an unsatisfactory record.

\section{Areas of Specialization}

Of 396 individuals responding to the question about area of specialization, 33.8 percent categorized themselves as being in the field of library administration, 3.8 percent in library operations, 51.3 percent in library education, and 11.1 percent in library research, as distinct from any of the above. It is assumed that this last grouping includes individuals in government posts, in commercial firms having research contracts, and in academic institutions but without teaching responsibilities.

Respondents indicated a remarkably high degree of contentment with their present areas of activity, although; as pointed out above, the subjectivity of self-perception must be taken into account. Of doctorate library administrators, 76.1 percent in fact stated that they preferred administration to other areas, with education running a distant second at 10.9 percent. Of individuals in library operations, 53.3 percent preferred this activity, while 26.7 percent indicated that they would prefer administration, an assignment they probably view as a promotional opportunity.

Of the library educators who make up more than half the survey, a remarkably high 86.7 percent express a preference for their present area of activity, with only 7.1 percent indicating a preference for administrative posts. Along the same lines, 67.6 percent of the individuals calling themselves researchers expressed a preference for their present line of work.

While such statements indicate a high degree of job satisfaction or at least adjustment, they also suggest a high degree of compartmentalization and specialization. Individuals who choose to teach without prior operational or administrative experience are unlikely to acquire it at a later date. Even doctoral graduates who chose not to teach initially seem unlikely to do so in the future. As a result, insofar as it is considered desirable that library school faculty have operational experience in the areas in which they teach, it can be postulated that they must achieve it before they become doctoral candidates. If they enter faculty ranks upon receipt of their doctorates without prior operational or administrative experience, it does not appear from the survey data that they will be likely to acquire it later.

\section{Evaluation of the Doctorate}

Respondents were asked to evaluate the 
doctorate in obtaining and in performing their present duties by indicating whether they considered the degree essential, important, useful, or unimportant. With a weight factor of three for essential, two for important, one for useful, and zero for unimportant, respondents as a whole gave an average weight of 2.40 to the doctorate in obtaining their present posts and 1.99 in performing them. As might be expected, library educators gave the doctorate the highest rating, with 2.81 for obtaining their posts and 2.33 for performing them. Nevertheless, an average difference in rating of almost half a point from 196 library educators who responded to this question is not insignificant. Administrators ranked second, with a 2.06 rating for obtaining the position, 1.73 for performing it. As expected, personnel in library operations ranked the degree lowest, with a 1.20 rating for obtaining the position and a 1.07 rating for performing it.

Perhaps most surprising is the fact that self-professed researchers ranked the doctorate at an average of 1.86 in obtaining their posts and at 1.51 in performing them. (See table 1 for a summary of all responses.) Since this evaluation of what is fundamentally a research degree for the purpose of doing research ranks below that of administrators, as well as educators, it may be (although the survey did not seek to determine this) that a greater proportion of these researchers work in nonacademic settings where the value placed on the doctoral degree is not as automatic.

Survey respondents were asked whether they had taught and, if so, whether they had supervised the research of doctoral students. Of the respondents who answered this question, 136 had supervised doctoral students, 160 had not. The responses of this subgroup of individuals to the question that elicited their views concerning the importance of the doctorate in obtaining and in performing their tasks were then evaluated. Their responses differed somewhat from those of library educators as a whole, since some of the individuals who classified themselves as teachers were only teaching on a part-time basis and preferred to categorize themselves primarily as administrators or as researchers. Others had taught but were no longer doing so. Nevertheless, while the specific numerical values differ from those reported in table 1 , the relationships remain closely consistent.

Those who as teachers were supervising or had supervised doctoral research rated the doctorate at a mean of $\mathbf{2 . 7 5}$ for obtaining their posts and at a mean of 2.33 for performing their duties. The same approximately .5 self-perceived overqualification differential noted earlier appears here as well. Those teachers who did not supervise doctoral research rated the importance of the degree in obtaining their posts at 2.30, in performing them at 2.07 .

\section{Pre- and Postdoctoral \\ Experience and Publications}

The Lane study mentioned earlier indicated a correlation between predoctoral experience and postdoctoral publication and between predoctoral publication and post-

TABLE 1

IMPORTANCE OF DOCTORATE FOR OBTAINING AND PERForming Present Post

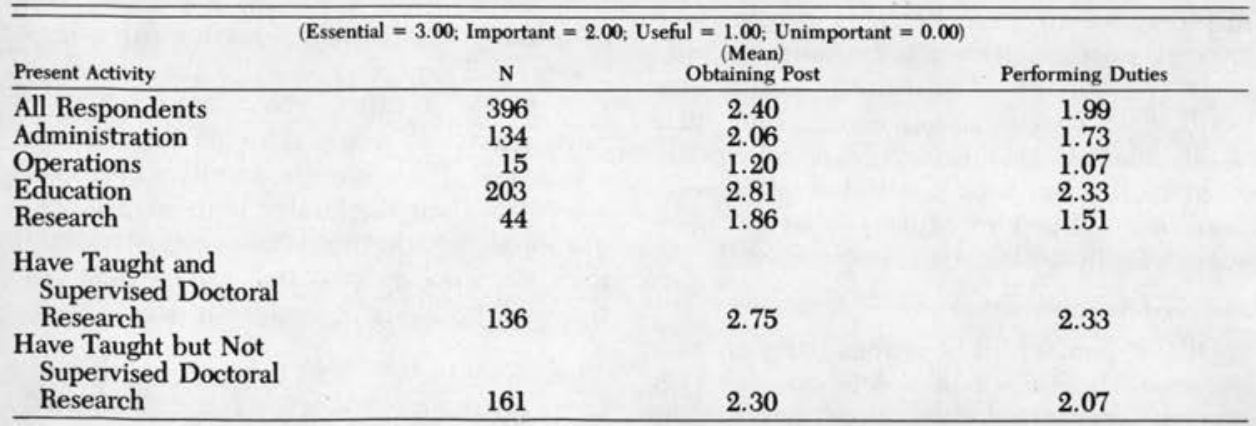


doctoral publication. Individuals who had more experience before receiving their doctorates, according to Lane, published more after receiving it than those who had had less experience. Similarly, individuals with a record of publication prior to the receipt of their doctorate were more apt to publish afterwards than those who had none. As Lane points out, her statistics were drawn simply from author listings in Library Literature and made no attempt at evaluating the kind of literature being reported.

In our survey, correlations were drawn between predoctoral professional experience (both in and out of the library field) and published research prior to and after receipt of the doctorate. Even though the responses to these questions carry a bias in that the evaluation of what constitutes research is left to the authors (who are likely to be more charitable in evaluating their work as research than an outsider would be), both prior experience and prior research publication appear to bear no positive relation to postdoctoral research. In fact, there is even a slight negative correlation. (See table 2.)

Since almost all respondents answered this series of questions, it can be seen not only that the sheer quantity of professional experience brought to the doctorate has little impact on later research activity (as measured by a self-evaluated record of publication) but also that there is an average of less than one research publication per postdoctoral year. No attempt was made in this survey to determine the kind of professional experience prior to the doctorate. If any correlations or prediction models are to be drawn, such an investigation would appear highly desirable.

The correlation of predegree research publication with postdegree research also seems to be insignificant (see table 3 ), although the number of annual publications since receipt of the degree for this group of respondents is consistently higher than that for the predoctoral reporting group. There was a difficulty in obtaining useful data for this group in that about half of the survey respondents, while often willing to discuss predoctoral experience, were not willing or able to furnish data concerning their predegree research publications. No correlation with postdegree publication could be attempted.

The hypothesis can be advanced that individuals unable or unwilling to report predoctoral publications had little or nothing to

TABLE 2

Predoctoral Experience as Related to POSTDOCTORAL Research Publication

\begin{tabular}{cc}
\hline $\begin{array}{c}\text { No. of Years Predoctoral } \\
\text { Professional Experience }(\mathrm{N}=255)\end{array}$ & $\begin{array}{c}\text { Research Publications/Year } \\
\text { Since Doctorate }\end{array}$ \\
\hline Less than 1 year & 1.06 \\
$1-3$ years & 0.87 \\
$4-6$ years & 0.65 \\
$7-10$ years & 0.69 \\
$11-15$ years & 0.93 \\
More than 15 years & 0.64 \\
\hline
\end{tabular}

TABLE 3

Predoctoral Research Publications as Related to Postdoctoral RESEARCH PUBLICATIONS

\begin{tabular}{cc}
\hline \hline $\begin{array}{c}\text { No. of Predoctoral } \\
\text { Research Publications }(\mathbf{N}=184)\end{array}$ & $\begin{array}{c}\text { Postdoctoral } \\
\text { Research Publications/Year } \\
\text { Since Doctorate }\end{array}$ \\
\hline 0 & 1.33 \\
1 & 0.73 \\
2 & 0.81 \\
4 & 1.13 \\
5 & 1.25 \\
6 & 0.74 \\
7 & 1.00 \\
8 or more & 0.76 \\
\hline
\end{tabular}


report. While this might seem absurd in an anonymous survey, it has already been reported that a great many respondents felt constrained to explain what they considered to be an inadequate record even though no one knew who they were. Although we know that these reports of postdoctoral research are exaggerations because they would produce a greater volume of research publication than appears in print, it is clear that the patterns apparent in the Lane study, which measured only publication count, disappear when authors are asked to count their own research publications.

\section{Failure to Conduct Research}

Individuals who, by their own assessment, had not performed or at least not published the results of postdoctoral research, were asked to explain why. Their reasons are summarized in table 4 . The explanation by 61.7 percent that failure to do more research was due to their being too busy matches the conclusions of Pauline Wilson in a recent article. ${ }^{5}$ In it the author points out that there is increasing pressure on library school faculty for research and publication and suggests that, as a result of shifting priorities, teaching may have to be done less well and participation in professional activities may have to be curtailed. Wilson may be correct, but these authors view her conclusions with at least some skepticism.

Wilson does point out that some faculty do no research simply because they are not interested, and we would suggest that to the 6 percent in our survey who indicated no interest and the 18.7 percent who did no research because it was not required could be added a considerable portion of the 68.9 percent who blame somebody else (too heavy a teaching load, no support, etc.). This last argument can neither be attacked nor defended, because it is not possible to determine whether faculty producing no research are already working as hard as they could be or as hard as they ought to be. As Wilson points out, much of the test will come with increased requirements of library faculty research for promotion and tenure, but only if at the same time safeguards against the dilution of teaching quality are imposed.

The almost 25 percent who have no interest in doing research unless required are of particular interest. One wonders for what reason these individuals sought a research terminal degree.

Cynics might respond that the degree is merely required to obtain the "union card" to admit the successful candidate to a more desirable kind or level of employment and is unrelated to research. A number of respondents made this and similar points in their unsolicited comments. If this attitude does indeed exist to any appreciable degree, it would point to a regrettable laxness on the part of library school administrations in the acceptance criteria employed for candidates, in the values that are stressed and implanted, and in the requirements that are met.

\section{Importance of the Doctorate}

The importance of the earned doctorate for faculty in library schools in establishing and retaining status for the school within its own academic setting is recognized, cannot be ignored, and is probably behind much of the recent upgrading in educational requirements for faculty in library schools. In fact, schools that have recently undergone ALA accreditation visits recognize the stress placed by the accreditation teams on both the number and diversity of earned doctorates as an indication of faculty competence.

Nevertheless, it would appear that a bal-

TABLE 4

REASONS STATED FOR PAUCITY OF RESEARCH

\begin{tabular}{lc}
\hline \hline Reason & Percent \\
Too busy & $61.7 \%$ \\
Research not required & $18.7 \%$ \\
Facilities lacking & $7.2 \%$ \\
Too recent & $6.4 \%$ \\
Not interested & $6.0 \%$ \\
\hline
\end{tabular}


ance must be struck between the emphasis on the terminal degree and the emphasis on other qualifications, where all are not equally available. To require, for example, as one school has done, a doctorate to teach courses in special librarianship automatically eliminates by fiat almost all of the people qualified to deal with special librarianship from experience. Perhaps it is necessary for library schools to insist, as other professional schools have done, on different kinds of faculties for different courses, In schools of music, for example, there are differences in the background and requirements for teaching a course in music history and theory and for teaching performance classes.

To some extent library schools have attempted to offset these limitations by using adjunct and visiting faculty who do not possess other absolute requirements. However, such opportunities are usually limited to schools in or near large metropolitan centers and in any case tend to fail to provide continuity and stability of employment, participation of the individual in the governance decisions of the school, and a sequence of priorities in which course teaching becomes something more than a spare time avocation.

\section{THE DOCTORATE AND RESEARCH}

The substantial increase in library doctorates should reasonably be expected to cause a sharp upsurge in both the amount and quality of library research. To the extent to which this has not occurred, it may be because so many of the doctoral graduates are new (more than half, as indicated at the beginning of this article, have had their degrees less than five years); it may be be- cause, as Wilson points out, opportunities for research are lacking; or it may be, as we suspect, that many library doctoral graduates (not unlike the doctoral graduates in other fields) are not particularly interested in research and publication, at least not at the expense of other professional and personal activities.

The existence of doctoral graduates (in the library field as in others) who admit to having no interest in research-and it can be assumed that the real number is larger than the 24.7 percent in this survey who admit doing no research unless forced towould appear to be a sharp indictment of the quality of present doctoral programs: in their selection criteria, in communicating to students the conditions and responsibilities of what the terminal degree means and requires, in the school's treatment of research, and in the acceptance of lesser standards in the undertaking of research leading to the dissertation.

The fact that only 22.6 percent of the survey respondents claimed any sort of even partially experimental approach in their dissertations, even in conjunction with other techniques, while more than 32 percent chose historical topics (see table 5) may suggest a paucity of innnovation and initiative. Opportunities for Ph.D. students in other disciplines to learn research techniques are provided at two levels, explicitly within the curriculum as a course and implicitly through actual work as an apprentice on a professor's research project. The lack of enthusiasm for and commitment to research by many respondents to this survey may well curtail the amount of "laboratory" experience possible in a library school setting.

TABLE 5

Characterization OF DisSERTATION TOPIC

\begin{tabular}{lcc}
\hline & (Mutually Exclusive) & Percent \\
\hline Historical & Number & $28.6 \%$ \\
Survey & 116 & $33.5 \%$ \\
Experimental & 136 & $20.4 \%$ \\
Other & 83 & $10.8 \%$ \\
Historical-Survey & 44 & $3.2 \%$ \\
Historical-Experimental & 13 & 0 \\
Historical-Other & 0 & $0.5 \%$ \\
Survey-Experimental & 2 & $1.7 \%$ \\
Survey-Other & 7 & $0.3 \%$ \\
Experimental-Other & 1 & $0.5 \%$ \\
No Answer & 2 & $0.5 \%$ \\
\hline
\end{tabular}


The most frequent justification stated in the survey responses for lack of research is that there is not sufficient time. If adequate instruction and learning experience in research techniques are not provided by the library schools themselves, then not only $\mathrm{Ph}$.D. students but also postdoctoral faculty members now pressured to produce research will be forced to find the time to develop these skills in addition to and before fulfilling the research requirements now increasingly imposed for promotion and tenure.

Other questions, which this investigation into the characteristics of our rapidly growing body of doctoral graduates suggests but must leave to later investigations to answer, concern the changes in the perceptions of these graduates that the pursuit and attainment of the degree may or may not bring about. Does it, in any measurąble way, change or sharpen their attitudes toward the profession, toward the role of the librarian, their own responsibilities, and the place, importance, or direction of research? Aside from the fact that it may enhance the status of librarianship in the academic setting, what difference will there be for the profession in 1980 , when we have 1,000 doctoral graduates, as compared to 1972 , when we had half as many, or 1966, when we had less than 250?

We assume that the identifying, undertaking, completing, and reporting of research needed by the profession (and certainly pro- fessions, perhaps unlike trades, have such needs), coupled with the training of still more future researchers, are the roles that our present and future library Ph.D.s are best and uniquely qualified to fill. Their acceptance of a research doctorate appears to embrace such a commitment. If it actually does, they can strengthen a bridge between library and information research and library and information operations, which is either in a serious state of disrepair or which has never even been completed. Evidence for assuming this bridging problem is the disdain practitioners express for the significance of the results of completed research, research they (rightly or wrongly) consider largely irrelevant. ${ }^{6}$

If library doctoral graduates do not accept a continuing commitment to research, and if they simply use the degree as a passport into the perceived safety and security of the library teaching profession (whether or not that safety and security are real), then an implication of this study is that the growth of doctoral programs could have the serious effect of widening the gap between those who teach and those who do not. This will almost certainly occur if perceptions of what makes an acceptable library teacher and an acceptable library administrator continue to move in opposite directions and if future doctoral graduates show the same tendencies to remain in their professional niches as the respondents to this survey have reported.

\section{REFERENCES}

1. Ray L. Carpenter and Patricia A. Carpenter, "The Doctorate in Librarianship and an Assessment of Graduate Library Education," Journal of Education for Librarianship 11:345 (Summer 1970).

2. David H. Eyman, comp., Doctoral Dissertations in Library Science: Titles Accepted by Accredited Library Schools 1930-72 (Ann Arbor, Mich.: Xerox University Microfilms, 1973).

3. Nancy D. Lane, "Characteristics Related to Productivity among Doctoral Graduates in Librarianship" (Ph.D. dissertation, Univ. of California, Berkeley, 1975).

4. David Kaser, "The Effect of the Revolution of
1969-1970 on University Library Administration," in Herbert Poole, ed., Academic Libraries by the Year 2000: Essays Honoring Jerrold Orne (New York: Bowker, 1977), p.64-75.

5. Pauline Wilson, "Barriers to Research in Library Schools: A Framework for Analysis," Journal of Education for Librarianship 17:319 (Summer 1976).

6. American Society for Information Science, "An Investigation of Planning Requirements and Priorities of the Scientific and Technical Information Community." Report on research sponsored by the National Science Foundation, presented at the ASIS annual meeting in Boston, October 1975. To be published. 